\title{
Aerobic mitochondrial capacities in Antarctic and temperate eelpout (Zoarcidae) subjected to warm versus cold acclimation
}

Received: 3 September 2004/ Revised: 15 February 2005/ Accepted: 3 March 2005 / Published online: 15 April 2005

(C) Springer-Verlag 2005

\begin{abstract}
Capacities and effects of cold or warm acclimation were investigated in two zoarcid species from the North Sea (Zoarces viviparus) and the Antarctic (Pachycara brachycephalum) by investigating temperature dependent mitochondrial respiration and activities of citrate synthase (CS) and NADP $^{+}$ -dependent isocitrate dehydrogenase (IDH) in the liver. Antarctic eelpout were acclimated to $5^{\circ} \mathrm{C}$ and $0^{\circ} \mathrm{C}$ (controls) for at least 10 months, whereas boreal eelpout, Z. viviparus (North Sea) were acclimated to $5^{\circ} \mathrm{C}$ and to $10^{\circ} \mathrm{C}$ (controls). Liver sizes were found to be increased in both species in the cold, with a concomitant rise in liver mitochondrial protein content. As a result, total liver state III rates were elevated in both cold-versus and warm-exposed $P$. brachycephalum and $Z$. viviparus, with the highest rates in boreal eelpout acclimated to $5^{\circ} \mathrm{C}$. CS and IDH activities in the total liver were similar in Z. viviparus acclimated to $5^{\circ} \mathrm{C}$ and $10^{\circ} \mathrm{C}$, but decreased in those warm acclimated versus control $P$. brachycephalum. Enzyme capacities in the total liver were higher in eelpout from Antarctica than those from the North Sea. In conclusion, cold compensation of aerobic capacities in the liver seems to be linked to an increase in organ size with unchanged specific mitochondrial protein content. Despite its life in permanently cold climate, $P$. brachycephalum was able to reduce liver aerobic capacities in warm climate and thus, displayed a capacity for temperature acclimation.
\end{abstract}

G. Lannig $(\bowtie) \cdot$ D. Storch $\cdot$ H.-O. Pörtner

Alfred Wegener Institute for Marine and Polar Research, Am Handelshafen 12, 27570

Bremerhaven, Germany

E-mail: glannig@awi-bremerhaven.de

Tel.: + 49-471-48311288

Fax: + 49-471-48311149

\section{Introduction}

The geographical distribution of ectothermic species is related to the ambient temperature regime, and tolerance to fluctuations of habitat temperature exists only within certain limits (for review see Pörtner 2001; Pörtner 2002a). Living in extreme Antarctic environment appears to be associated with reduced tolerance to higher temperatures. Low upper-lethal temperatures have been observed in the Antarctic brachiopod, Liothyrella uva between $3^{\circ} \mathrm{C}$ and $4.5^{\circ} \mathrm{C}$ (Peck 1989). Pörtner et al. (1999a) found a short-term upper lethal temperature of $4^{\circ} \mathrm{C}$ and a long-term upper limit of around $2^{\circ} \mathrm{C}$ in the bivalve Limopsis marionensis. An upper-lethal temperature of $6^{\circ} \mathrm{C}$ was found in three species of the Antarctic fish Trematomus by Somero and de Vries (1967). Antarctic eelpout, Pachycara brachycephalum and the Notothenioid, Lepidonotothen nudifrons survived temperatures of up to $9-10^{\circ} \mathrm{C}$ (van Djik et al. 1999; Hardewig et al. 1999), and Mark et al. (2002) reported a lethal temperature of $P$. brachycephalum at around $13^{\circ} \mathrm{C}$. Reduced heat tolerance in cold-stenothermal ectotherms is likely linked to cold induced functional adaptations, which compensate for the decelerating effect of low temperatures on metabolic processes.

Mitochondrial proliferation has been found in cold adapted Southern and Northern hemisphere species (Londraville and Sidell 1990; Johnston et al. 1998; Sommer and Pörtner 2002) as well as in cold acclimated eurythermal species (Campbell and Davies 1978; Egginton and Sidell 1989). Furthermore, enhanced enzyme activities are found in cold adapted as well as in cold acclimated animals (Crockett and Sidell 1990; Sokolova and Pörtner 2001; Kawall et al. 2002; Lannig et al. 2003). Besides enhanced mitochondrial densities, an increase in total organ size has also been reported to compensate for the effects of low temperatures (Kent et al. 1988 (liver and heart); Seddon and Prosser 1997 (liver); Lannig et al. 2003 (liver)). 
Despite compensatory increase in tissue aerobic capacities, Antarctic animals show uncompensated resting metabolic rates (Clarke 1991; van Dijk et al. 1999; for review see Pörtner et al. 2000; Peck 2002) and uncompensated specific maximal respiration rates of mitochondria (Johnston et al. 1994; Johnston et al. 1998; Pörtner et al. 1999b; Hardewig et al. 1999). Pörtner et al. (2000) suggested that mitochondrial and whole animal aerobic capacities remain uncompensated only in coldstenothermal organisms, as opposed to cold adapted eurytherms. This may also be associated with the inability of cold-stenotherms to acclimate to warmer temperatures (e.g. Weinstein and Somero 1998).

The adjustment of aerobic scope by setting mitochondrial densities and capacities is seen as a crucial step in shifting thermal tolerance windows (cf. Pörtner 2002a). The present study was designed to investigate the ability to adjust aerobic metabolism to changing temperature in Antarctic compared to temperate eurythermal fish. We wanted to investigate whether a demersal Antarctic species like P. brachycephalum is able to undergo adjustments in aerobic metabolism to various temperatures despite living in a cold-stable environment. If so, the question arises whether the patterns of temperature compensation are similar for stenothermal and eurythermal ectotherms. Accordingly, the response to a $5^{\circ} \mathrm{C}$ temperature change was compared in closely related members of the zoarcid fish family. We acclimated cold adapted Antarctic eelpout, P. brachycephalum, from $0^{\circ} \mathrm{C}$ to $5^{\circ} \mathrm{C}$, whereas temperate common North Sea eelpout, Zoarces viviparus were acclimated from $5^{\circ} \mathrm{C}$ to $10^{\circ} \mathrm{C}$. We investigated mitochondrial respiration rates and the enzyme activities of citrate synthase (CS) and $\mathrm{NADP}^{+}$-dependent isocitrate dehydrogenase (IDH) in liver mitochondria at different temperatures. CS was chosen as an indicator of citric acid cycle activity and IDH as representing a key role in a mitochondrial substrate cycle, which may be relevant in the control of mitochondrial respiration, redox status and proton leakage (Sazanov and Jackson 1994; Pörtner et al. 1999b).

\section{Materials and methods}

Animals

Antarctic eelpout, $P$. brachycephalum were caught by baited traps close to King George Island (depth 397$455 \mathrm{~m}$ ) during the RV Polarstern Antarctic expedition $\mathrm{XV} / 3$ 1998. The fish were kept in aquaria onboard the RV Polarstern and later at the Alfred Wegener Institute (Bremerhaven) at ambient temperatures of $0 \pm 0.5^{\circ} \mathrm{C}$ and a salinity of $34 \%$. North Sea eelpout, Z. viviparus were caught in the German Bight near Helgoland (in August 2001 and in March 2002) and kept in aquaria at the Alfred Wegener Institute at temperatures of $10 \pm 1^{\circ} \mathrm{C}$ and a salinity of $34 \%$. Acclimation to $5^{\circ} \mathrm{C}$ started in spring 2002, with Antarctic and North Sea eelpouts placed in the same aquarium at $5 \pm 0.5^{\circ} \mathrm{C}$ and a salinity of $34 \%$. Other animals remained at control temperatures. All animals were kept under a 12:12-h light-dark cycle and fed live shrimp once per week. Experiments were carried out at the start of 2003, after an acclimation period at $5^{\circ} \mathrm{C}$ of at least 10 months.

\section{Preparation of mitochondria}

The isolation of mitochondria was modified after Hardewig et al. (1999). After the fish were killed, the liver was removed immediately, chopped finely with scissors in an ice-cold glass dish, and extracted in 10 $25 \mathrm{ml}$ of homogenisation buffer, depending on liver wet mass, approximately $0.5 \mathrm{~g}$ per $10 \mathrm{ml}(50 \mathrm{mM}$ Hepes, $80 \mathrm{mM}$ sucrose, $85 \mathrm{mM} \mathrm{KCl}, 5 \mathrm{mM}$ EDTA, $5 \mathrm{mM}$ EGTA, pH $7.1\left(20^{\circ} \mathrm{C}\right)$ with freshly added $1 \%$ BSA and $1 \mu 1 \mathrm{ml}^{-1}$ aprotinin) with a Potter-Elvejhem homogeniser. After centrifugation $\left(12 \mathrm{~min}\right.$ at $400 \mathrm{~g}$ and $\left.0^{\circ} \mathrm{C}\right)$ the pellet was re-homogenised in the same volume of homogenisation buffer and centrifuged again. The combined supernatants were centrifuged for $8 \mathrm{~min}$ at $10,000 \mathrm{~g}$ and $0^{\circ} \mathrm{C}$. The mitochondrial pellet was resuspended in 1-2 $\mathrm{ml}$ assay medium $(50 \mathrm{mM}$ Hepes,

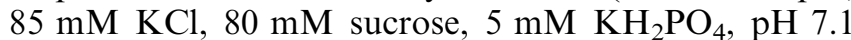
$\left(20^{\circ} \mathrm{C}\right)$ with freshly added $1 \%$ BSA and $1 \mu 1 \mathrm{ml}^{-1}$ aprotinin). In some cases the livers of two animals were pooled to enhance the volume of mitochondrial suspension but counted as one in the statistical analyses and results.

\section{Mitochondrial respiration and enzyme assays}

Mitochondrial oxygen consumption was measured at different temperatures $\left(5,8,10,15\right.$ and $\left.20^{\circ} \mathrm{C}\right)$ using a Clark-type oxygen electrode in a thermostatted respiration chamber (Eschweiler, Kiel). A total of $100 \mu \mathrm{l}$ of the mitochondrial suspension were combined with assay medium, without BSA and aprotinin, to a total volume of $1 \mathrm{ml}$, containing $0.5-1.2 \mathrm{mg}$ mitochondrial protein per millilitre, $5 \mu \mathrm{M}$ di-adenosine pentaphosphate $\left(\mathrm{Ap}_{5} \mathrm{~A}\right.$, an inhibitor of myokinase) and $3.3 \mathrm{mM}$ succinate as a substrate since respiration showed lower rates using pyruvate and malate. State III respiration was recorded after addition of $0.3 \mathrm{mM}$ ADP and state VI respiration was determined after all ADP had been phosphorylated. Finally, the respiration induced by proton leakage (state $\mathrm{IV}_{\mathrm{ol}}$ ) was recorded after adding $2.5 \mu \mathrm{g} \mathrm{ml}^{-1}$ oligomycin, an inhibitor of mitochondrial $\mathrm{F}_{0} \mathrm{~F}_{1}$-ATPase. $\mathrm{P} / \mathrm{O}$ ratios were calculated by classical determination according to Chance and Williams (1956). Mitochondrial oxygen consumption was calculated as nanomole $\mathrm{O}$ min $^{-1} \mathrm{mg}$ protein ${ }^{-1}$ by adopting values of oxygen solubility in the assay medium from Johnston et al. (1994). Protein concentration was determined by the Biuret method after Gornall et al. (1949) using 5\% deoxycholate to solubilize membrane proteins. 
Since the high lipid content in liver disturbed the photometric measurements, $3 \mathrm{M}$ TCA was used to precipitate and separate the protein by centrifugation for $15 \mathrm{~min}$ at $16,000 \mathrm{~g}$ and $15^{\circ} \mathrm{C}$. The pellet was re-suspended with $1 \mathrm{ml}$ diethylether and ethanol (4:1) and, after re-centrifugation, the pellet was re-suspended with $0.2 \mathrm{ml} \mathrm{H}_{2} \mathrm{O}$ and $1 \mathrm{ml}$ Biuret reagent. Since the extraction of mitochondria was still incomplete, mitochondrial protein content per gram of liver was calculated from comparisons of CS activities measured in the mitochondrial suspension and in liver tissue extracts $(100 \%$ CS).

Citrate synthase activity was quantified in the mitochondrial suspension, specified in units per milligram of mitochondrial protein, and in liver tissue (units per $\mathrm{g}$ wet wt tissue) using a modified procedure after Sidell et al. (1987). Mitochondrial suspension was added to assay medium (2:1) and, after 15 min of ultrasonic treatment at $0^{\circ} \mathrm{C}$ (output control 8, duty cycle $50 \%$, Branson Sonifier 450, Heinemann Ultraschalltechnik, Germany), was centrifuged for $5 \mathrm{~min}$ at $7,400 \mathrm{~g}$ and $0^{\circ} \mathrm{C}$.

For the determination of CS activity in liver tissue $(100 \% \mathrm{CS})$ approximately $0.02 \mathrm{~g}$ of tissue (taken after chopping the liver during the preparation of isolated mitochondria isolation) were added to $1 \mathrm{ml}$ of assay medium without BSA and aprotinin, subjected to ultrasonic treatment (15 min, output control 8, duty cycle $50 \%$ at $0^{\circ} \mathrm{C}$ ) and centrifuged for $5 \mathrm{~min}$ at $7,400 \mathrm{~g}$ and $0^{\circ} \mathrm{C}$. The supernatants were kept on ice and enzyme activities remained stable for at least $24 \mathrm{~h}$. CS activity was determined in $100 \mathrm{mM}$ Tris- $\mathrm{HCl}, \mathrm{pH} 8\left(20^{\circ} \mathrm{C}\right)$, $5 \mathrm{mM}$ DTNB, $20 \mathrm{mM}$ Acetyl-CoA, $20 \mathrm{mM}$ oxaloacetate. The increase in absorbance at $412 \mathrm{~nm}$ was monitored in a thermostatted spectrophotometer at 5, 10, 15 and $20^{\circ} \mathrm{C}$, respectively. Enzyme activity was calculated using an extinction coefficient $\left(\epsilon_{412}\right)$ for DTNB of $13.611 \mathrm{mmol}^{-1} \mathrm{~cm}^{-1}$.

For the determination of $\mathrm{NADP}^{+}$-dependent IDH activity, mitochondrial suspension was added to stabilisation buffer $(2: 1$; containing $50 \mathrm{mM}$ Hepes, $85 \mathrm{mM}$

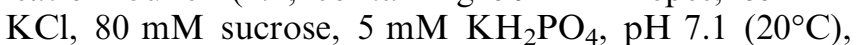
$2 \mathrm{mM}$ DTT, $20 \mathrm{mM} \mathrm{MgCl}, 20 \mathrm{mM}$ isocitrate and $5 \mathrm{mM}$ EDTA), treated for $5 \mathrm{~min}$ at $0^{\circ} \mathrm{C}$ in an ultrasonic bath (output control 2, duty cycle $50 \%$ ) and centrifuged for $9 \mathrm{~min}$ at 7,400 $\mathrm{g}$ and $0^{\circ} \mathrm{C}$. The enzyme remained stable for more than $24 \mathrm{~h}$ after this treatment. IDH activity was measured after Alp et al. (1976), by monitoring the appearance of NADPH at $339 \mathrm{~nm}$ in a temperature controlled spectrophotometer at 5, 10, 15 and $20^{\circ} \mathrm{C}$, respectively. The assay contained $70 \mathrm{mM}$ Tris- $\mathrm{HCl}$ $\mathrm{pH} 7.1\left(20^{\circ} \mathrm{C}\right), 8 \mathrm{mM} \mathrm{MgSO}{ }_{4}, 2.5 \mathrm{mM} \mathrm{NADP}^{+}, 1 \mathrm{mM}$ $\mathrm{MnCl}_{2}, 3 \mathrm{mM}$ D/L-isocitrate and $20 \mathrm{mM}$ citrate. Enzyme activity was calculated using an extinction coefficient $\left(\epsilon_{339}\right)$ for NAD $(\mathrm{P}) \mathrm{H}$ of $6.31 \mathrm{mmol}^{-1} \mathrm{~cm}^{-1}$.

\section{Allometric scaling}

Since liver size and lipid content influence liver aerobic capacity available to the animal, we calculated total mitochondrial protein content, mitochondrial respiration rates and enzyme activities for total liver, normalized to a 40 g eelpout (see Pelletier et al. 1993; Lannig et al. 2003). Total mitochondrial protein content and total CS activities were calculated with the following formula:

$N=T \cdot\left(\frac{40}{\text { body mass }}\right)^{m}$,

where $N$ indicates normalized mitochondrial protein or normalized CS activity and $T$ indicates total mitochondrial protein or total CS activity. The body mass exponent ' $m$ ' was determined from the slope of the linear regression in a double logarithmic plot of mitochondrial protein or CS activity in total liver versus body mass in gram.

Mitochondrial respiration rates and IDH activity in total liver were calculated from the normalized protein content. No differences were found in total CS activity between direct normalization, described above, and calculation from normalized protein content.

Calculation of the hepatosomatic index as:

$I_{\mathrm{H}}=\frac{\text { liver mass }(\mathrm{g})}{\operatorname{body} \text { mass }(\mathrm{g})} \times 100$,

was carried out with normalized liver mass for a $40 \mathrm{~g}$ eelpout by the following formula:

Normalized liver mass $=$ exact liver $\times\left(\frac{40}{\text { body mass }}\right)^{m}$,

where the body mass exponent $\mathrm{m}$ was determined from the slope of the linear regression in a double logarithmic plot of liver mass versus body mass in grams. Data of animals and mass exponents for the different allometric scalings are summarized in Table 1.

\section{Statistical analyses}

All values are given as means ( \pm standard deviation). Statistical significance was tested at the $P=0.05$ level using analysis of variance (ANOVA, SigmaStat) and post hoc procedures (Tukey test). Before statistical testing, log transformations were used whenever necessary to meet statistical assumptions of the homogeneity of variances. However, non-transformed data are given in text and figures.

\section{Results}

Hepatosomatic index and mitochondrial liver protein content

Normalized hepatosomatic indices $\left(I_{\mathrm{H}}\right.$, Fig. 1) were significantly higher in cold-exposed than in warm-exposed North Sea and Antarctic eelpout. $I_{\mathrm{H}}$ was lowest in $Z$. viviparus acclimated to $10^{\circ} \mathrm{C}$. However, no 
Table 1 Body and liver masses, condition factors (k-factor), gonadosomatic indices $\left(I_{G}\right)$ and mass exponents $(m)$ of regression equations (with $P$ values) for the normalization to a 40 -g specimen of the two eelpout species, Z. viviparus (North Sea) and P. brachycephalum (Antarctica) from the different acclimation groups

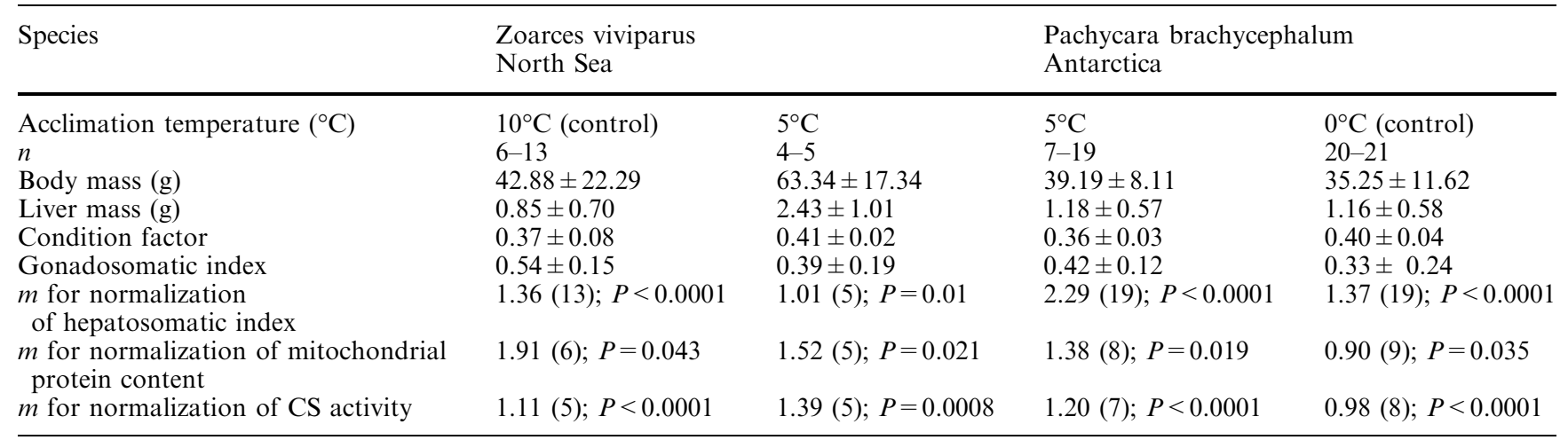

Numbers of experimental animals are shown in parentheses. Data are means $\pm \mathrm{SD}$

differences were found between Z. viviparus acclimated to $5^{\circ} \mathrm{C}$ and $P$. brachycephalum acclimated to control conditions $\left(0^{\circ} \mathrm{C}\right)$. P. brachycephalum acclimated to $5^{\circ} \mathrm{C}$ showed a significantly lower $I_{\mathrm{H}}$ than $Z$. viviparus at $5^{\circ} \mathrm{C}$.

Specific mitochondrial protein contents (mg g liver $^{-1}$ ) were more or less similar in control and acclimation groups of one species as well as the two species. Values were $35.41 \pm 5.31$ (North Sea, $10^{\circ} \mathrm{C}$ ), $43.15 \pm 10.97$ (North Sea, $5^{\circ} \mathrm{C}$ ), $30.16 \pm 10.37$ (Antarctica, $5^{\circ} \mathrm{C}$ ) and $37.10 \pm 7.48$ (Antarctica, $0^{\circ} \mathrm{C}$ ) (means \pm standard deviation). Normalized protein content in total liver showed acclimation effects in both species, with higher values in cold compared to warm acclimated boreal and polar eelpout (Fig. 2). Species comparison revealed significantly higher mitochondrial liver protein in $P$. brachycephalum $\left(0^{\circ} \mathrm{C}\right.$ and $\left.5^{\circ} \mathrm{C}\right)$ compared to control $\left(10^{\circ} \mathrm{C}\right) Z$. viviparus, but similar total protein contents compared to $Z$. viviparus acclimated to $5^{\circ} \mathrm{C}$.

\section{Mitochondrial respiration}

Mitochondrial coupling of all groups was significantly higher when assayed at $5^{\circ} \mathrm{C}$ than at $20^{\circ} \mathrm{C}$. At $5^{\circ} \mathrm{C}$ respiratory control ratios $\left(\mathrm{RCR}_{\mathrm{ol}}\right.$, ratio of state III and state IV under oligomycin) were $4.85 \pm 1.29$ (North Sea, $10^{\circ} \mathrm{C}$ ), $8.37 \pm 1.13$ (North Sea, $5^{\circ} \mathrm{C}$ ), $4.39 \pm 0.93$ (Antarctica, $5^{\circ} \mathrm{C}$ ) and $4.87 \pm 1.08$ (Antarctica, $0^{\circ} \mathrm{C}$ ) (Fig. 3). The traditional RCR (ratio of state III and state IV without oligomycin, data not shown) was found to be only slightly lower than $\mathrm{RCR}_{\mathrm{ol}}$. Comparison of $\mathrm{RCR}_{\mathrm{ol}}$ between groups of $Z$. viviparus revealed significantly higher values in animals acclimated to $5^{\circ} \mathrm{C}$ than in controls $\left(10^{\circ} \mathrm{C}\right)$, whereas no acclimation effect was found in $\mathrm{RCR}_{\mathrm{ol}}$ of Antarctic eelpout. Coupling was significantly higher at all temperatures in North Sea eelpout acclimated to $5^{\circ} \mathrm{C}$ than in control and in $5^{\circ} \mathrm{C}$ acclimated Antarctic eelpout.

Determination of classical $\mathrm{P} / \mathrm{O}$ ratios yielded numbers between 1.5 and 2.5 for all acclimation groups assayed in
Fig. 1 Hepatosomatic indices, normalized to a $40 \mathrm{~g}$ animal, in Antarctic and North Sea

Zoarcidae, in $P$. brachycephalum (Antarctica) under control conditions $\left(0^{\circ} \mathrm{C}\right)$ $(n=19)$ and acclimated to $5^{\circ} \mathrm{C}$ $(n=19)$, in Z. viviparus (North Sea) acclimated to $5^{\circ} \mathrm{C}(n=5)$ and $10^{\circ} \mathrm{C}$ (control conditions, $n=13$ ). Data marked with the same letters are significantly different

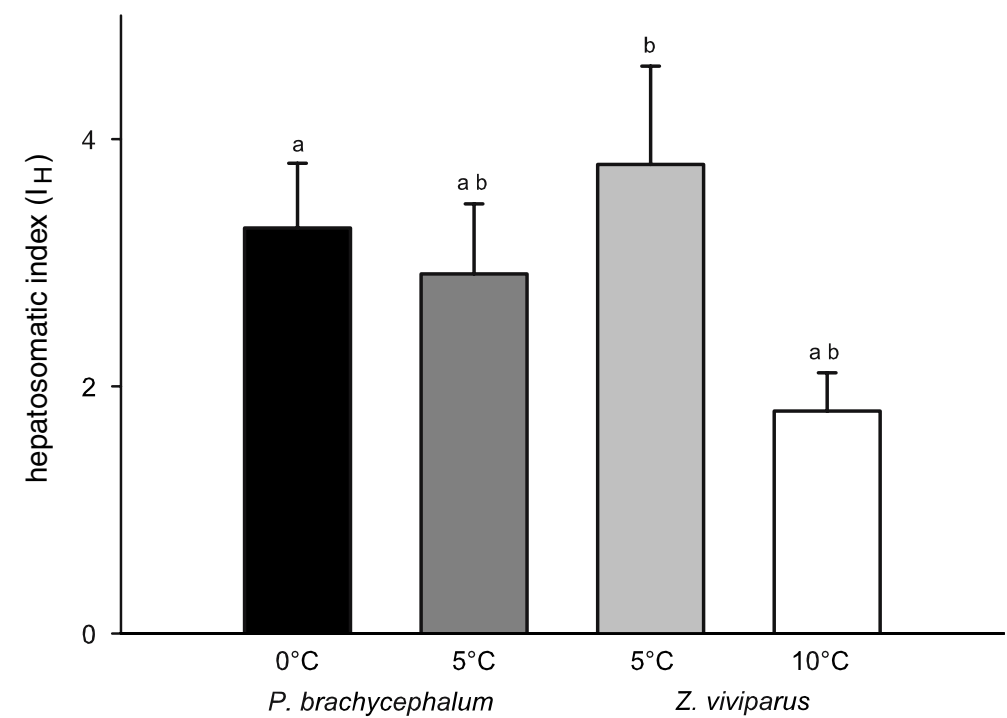


Fig. 2 Total mitochondrial protein content (normalized to Antarctic and North Sea Zoarcidae, in $P$. brachycephalum (Antarctica) under control conditions $\left(0^{\circ} \mathrm{C}\right)$ $(n=8)$ and acclimated to $5^{\circ} \mathrm{C}$ $(n=8)$, in Z. viviparus (North Sea) acclimated to $5^{\circ} \mathrm{C}(n=4)$ and $10^{\circ} \mathrm{C}$ (control conditions, $n=6$ ). Data marked with the same letters are significantly different a $40 \mathrm{~g}$ animal), in liver of

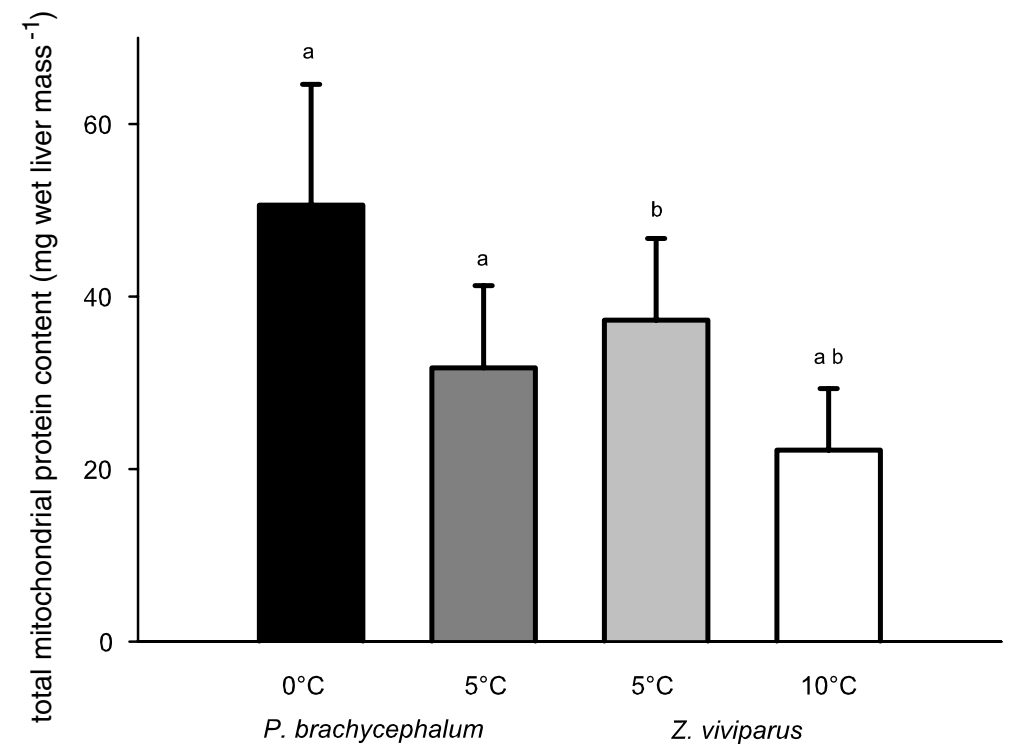

the temperature range of $5^{\circ} \mathrm{C}$ and $10^{\circ} \mathrm{C}$. Above $10^{\circ} \mathrm{C} \mathrm{P} / \mathrm{O}$ values of mitochondria from warm acclimated $P$. brachycephalum and $Z$. viviparus (at $20^{\circ} \mathrm{C}$ only) decreased significantly, resulting in significantly lower values compared to the more or less unchanged and temperature independent $\mathrm{P} / \mathrm{O}$ ratios of cold acclimated Antarctic and North Sea eelpout (data not shown).

Mitochondrial respiration rates $\left(\mathrm{nmol} \mathrm{O} \mathrm{min}^{-1} \mathrm{mg}\right.$ protein $^{-1}$; state III, state IV and state $\mathrm{IV}_{\mathrm{ol}}$ ) increased significantly with rising temperatures in all groups (data

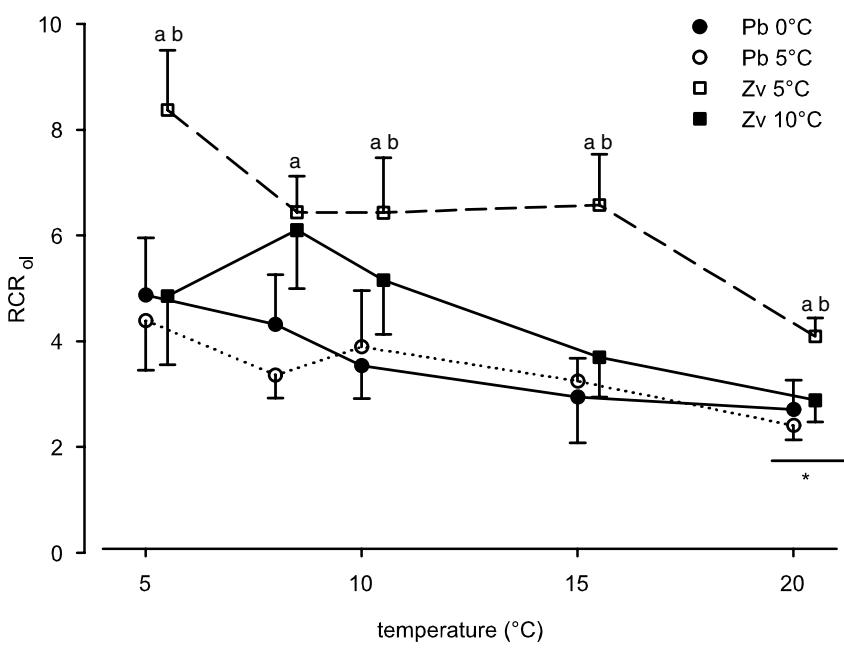

Fig. 3 Temperature dependence of respiratory coupling ratios under oligomycin $\left(\mathrm{RCR}_{\mathrm{ol}}\right)$ of mitochondria isolated from liver of Antarctic and North Sea Zoarcidae, in $P$. brachycephalum (Antarctica) under control conditions $\left(0^{\circ} \mathrm{C}\right)$ (filled circles $\left.n=4-8\right)$ and acclimated to $5^{\circ} \mathrm{C}$ (open circles $n=4-8$ ) and in $Z$. viviparus (North Sea) acclimated to $5^{\circ} \mathrm{C}$ (open squares $n=4-5$ ) and $10^{\circ} \mathrm{C}$ (control conditions, filled squares $n=4-6$ ). For better viewing squares were shifted to the right. * indicates values significantly different from those at $5^{\circ} \mathrm{C}$. a indicates $\mathrm{RCR}_{\mathrm{ol}}$ of $Z$. viviparus at $5^{\circ} \mathrm{C}$ significantly different to data from $P$. brachycephalum at $0^{\circ} \mathrm{C}$ and $5^{\circ} \mathrm{C}$, when compared at the same temperature. $\mathbf{b}$ indicates $\mathrm{RCR}_{\mathrm{ol}}$ of $Z$. viviparus at $5^{\circ} \mathrm{C}$ significantly different to data from $Z$. viviparus at $10^{\circ} \mathrm{C}$, when compared at the same temperature not shown), whereas acclimation had no effect on specific mitochondrial respiration within both species. When measured at $5^{\circ} \mathrm{C}$ specific state III respiration rates of North Sea eelpout were $11.5 \pm 3.7\left(10^{\circ} \mathrm{C}\right)$ and $14.2 \pm 3.5\left(5^{\circ} \mathrm{C}\right)$ and those of Antarctic eelpout were $6.8 \pm 2.1\left(0^{\circ} \mathrm{C}\right)$ and $9.7 \pm 1.4\left(5^{\circ} \mathrm{C}\right)$. Respiration rates were significantly lower in polar eelpout acclimated to $0^{\circ} \mathrm{C}$ than in boreal eelpout acclimated to $5^{\circ} \mathrm{C}$ and $10^{\circ} \mathrm{C}$, for state III at all temperatures and for state $\mathrm{IV}_{\mathrm{ol}}$ at $20^{\circ} \mathrm{C}$ only. Warm acclimated $P$. brachycephalum showed significant differences only in state III respiration, which was lower than in $Z$. viviparus controls $\left(10^{\circ} \mathrm{C}\right)$ at assay temperatures between $8^{\circ} \mathrm{C}$ and $15^{\circ} \mathrm{C}$. At investigated temperatures, no significant discontinuity in Arrhenius plots was found for all groups (data not shown). $Q_{10}$ values and Arrhenius activation energies $\left(E_{\mathrm{A}}\right)$ were similar in all groups: $P$. brachycephalum: state III: $Q_{10}=2.0 \pm 0.4, E_{\mathrm{A}}=49.2 \pm 11.9 \mathrm{~kJ} \mathrm{~mol}^{-1}$; state IV: $\mathrm{IV}_{\mathrm{ol}}: Q_{10}=3.2 \pm 0.8, E_{\mathrm{A}}=74.3 \pm 14.7 \mathrm{~kJ}^{-1}$ and Z. viviparus: state III: $Q_{10}=2.2 \pm 0.4, E_{\mathrm{A}}=53.4 \pm 10.5 \mathrm{~kJ}$ $\mathrm{mol}^{-1}$; state IV: $Q_{10}=3.2 \pm 0.8, \quad E_{\mathrm{A}}=76.9 \pm$ $17.5 \mathrm{~kJ} \mathrm{~mol}^{-1}$ and state $\mathrm{IV}_{\mathrm{ol}}: Q_{10}=3.2 \pm 0.5, E_{\mathrm{A}}=$ $79.8 \pm 8.6 \mathrm{~kJ} \mathrm{~mol}^{-1}$ (means \pm standard deviation for control and acclimation groups of each species).

Mitochondrial state III respiration normalized for total liver of a $40 \mathrm{~g}$ animal showed significant acclimation effects in both species (Fig. 4a). Respiration was higher in total liver of cold- exposed versus warm-exposed $Z$. viviparus and P. brachycephalum. Liver respiration capacities (state III) in $5^{\circ} \mathrm{C}$ acclimated boreal eelpout were significantly higher than in control $\left(0^{\circ} \mathrm{C}\right)$ and $5^{\circ} \mathrm{C}$ acclimated polar eelpout at all temperatures. However, total liver mitochondria of control $P$. brachycephalum $\left(0^{\circ} \mathrm{C}\right)$ respired at higher rates than total liver mitochondria of control $Z$. viviparus $\left(10^{\circ} \mathrm{C}\right)$. State IV respiration under oligomycin, which is assumed to quantify oxygen consumption due to proton leakage through the inner mitochondrial membrane $\left(\mathrm{IV}_{\mathrm{ol}}\right.$, $Q_{10}=2.9 \pm 0.7, \quad E_{\mathrm{A}}=67.1 \pm 12.9 \mathrm{~kJ} \mathrm{~mol}^{-1}$ and state 


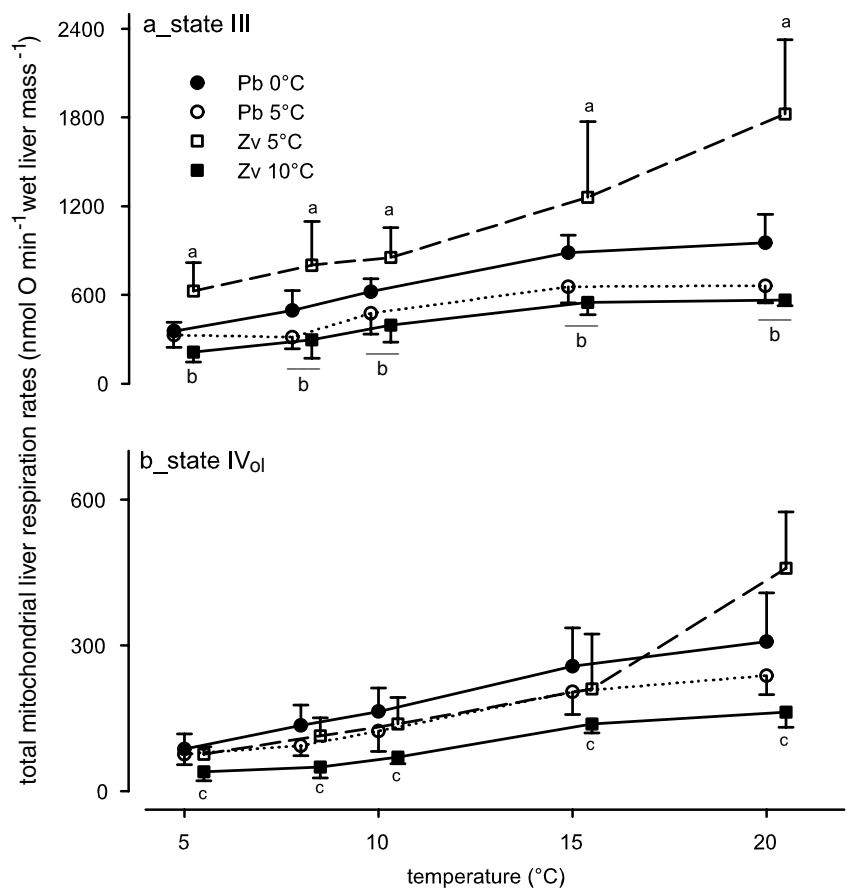

Fig. 4 Temperature dependence of total mitochondrial respiration rates, state III (a) and state IV $_{\mathrm{ol}}$ (b, state IV under oligomycin) in liver (normalized to a $4 \mathrm{~g}$ animal) of Antarctic and North Sea Zoarcidae, in $P$. brachycephalum (Antarctica) under control conditions $\left(0^{\circ} \mathrm{C}\right)$ (filled circles $\left.n=4-6\right)$ and acclimated to $5^{\circ} \mathrm{C}$ (open circles $n=4-8$ ) and in $Z$. viviparus (North Sea) acclimated to $5^{\circ} \mathrm{C}$ (open squares $n=4-5$ ) and $10^{\circ} \mathrm{C}$ (control conditions, filled squares $n=3-5$ ). For better viewing squares were shifted to the right. a indicates data from $Z$. viviparus at $5^{\circ} \mathrm{C}$ significantly different to data from the other acclimation groups, when compared at the same temperature. b indicates data from $P$. brachycephalum at $5^{\circ} \mathrm{C}$ and from $Z$. viviparus at $10^{\circ} \mathrm{C}$ significantly different to data from $P$. brachycephalum at $0^{\circ} \mathrm{C}$, when compared at the same temperature. c indicates data from $Z$. viviparus $10^{\circ} \mathrm{C}$ significantly different to data from the other acclimation groups, when compared at the same temperature

Fig. 4b), showed higher rates after cold acclimation in the total liver of $Z$. viviparus only, whereas state $\mathrm{IV}_{\mathrm{ol}}$ capacity remained similar in total liver of warm acclimated $\left(5^{\circ} \mathrm{C}\right)$ and control $\left(0^{\circ} \mathrm{C}\right) \mathrm{P}$. brachycephalum. State $\mathrm{IV}_{\mathrm{ol}}$ rates were again higher in the liver of $0^{\circ} \mathrm{C}$ and $5^{\circ} \mathrm{C}$ exposed Antarctic eelpout than of North Sea eelpout at $10^{\circ} \mathrm{C}$.

\section{Enzyme activities}

Citrate synthase activities in the mitochondrial suspensions ( $\mathrm{U} \mathrm{mg}$ mitochondrial protein ${ }^{-1}$ ) were similar in acclimated and control groups of both species (Fig. 5a). Control groups $\left(0^{\circ} \mathrm{C}\right)$ of Antarctic eelpout displayed significantly higher specific CS activities than both control and acclimation groups of North Sea eelpout. However, this difference decreased with warm acclimation and specific CS activity of liver mitochondria from $5^{\circ} \mathrm{C}$ acclimated $P$. brachycephalum was significantly higher only compared to those from $Z$. viviparus accli- mated to $5^{\circ} \mathrm{C}$. No discontinuities of Arrhenius plots were found in the investigated temperature range (data not shown) and $Q_{10}$ values and Arrhenius activation energies $\left(E_{\mathrm{A}}\right)$ were similar in all groups, with $Q_{10}=1.6 \pm 0.1$ and $E_{\mathrm{A}}=32.5 \pm 5.3 \mathrm{~kJ} \mathrm{~mol}^{-1}$ for $P$. brachycephalum and with $Q_{10}=1.6 \pm 0.1$ and $E_{\mathrm{A}}=33.5 \pm 4.2 \mathrm{~kJ} \mathrm{~mol}^{-1}$ for $Z$. viviparus (means \pm standard deviation for control and acclimation groups of each species). CS activities in the total liver of a $40 \mathrm{~g}$ animal again showed again no differences between groups of Z. viviparus, whereas higher total CS activities were found in control $\left(0^{\circ} \mathrm{C}\right)$ compared to $5^{\circ} \mathrm{C}$ acclimated $P$. brachycephalum (Fig. 5b). The normalized liver of Antarctic eelpout $\left(0^{\circ} \mathrm{C}\right.$ and $\left.5^{\circ} \mathrm{C}\right)$ displayed significantly
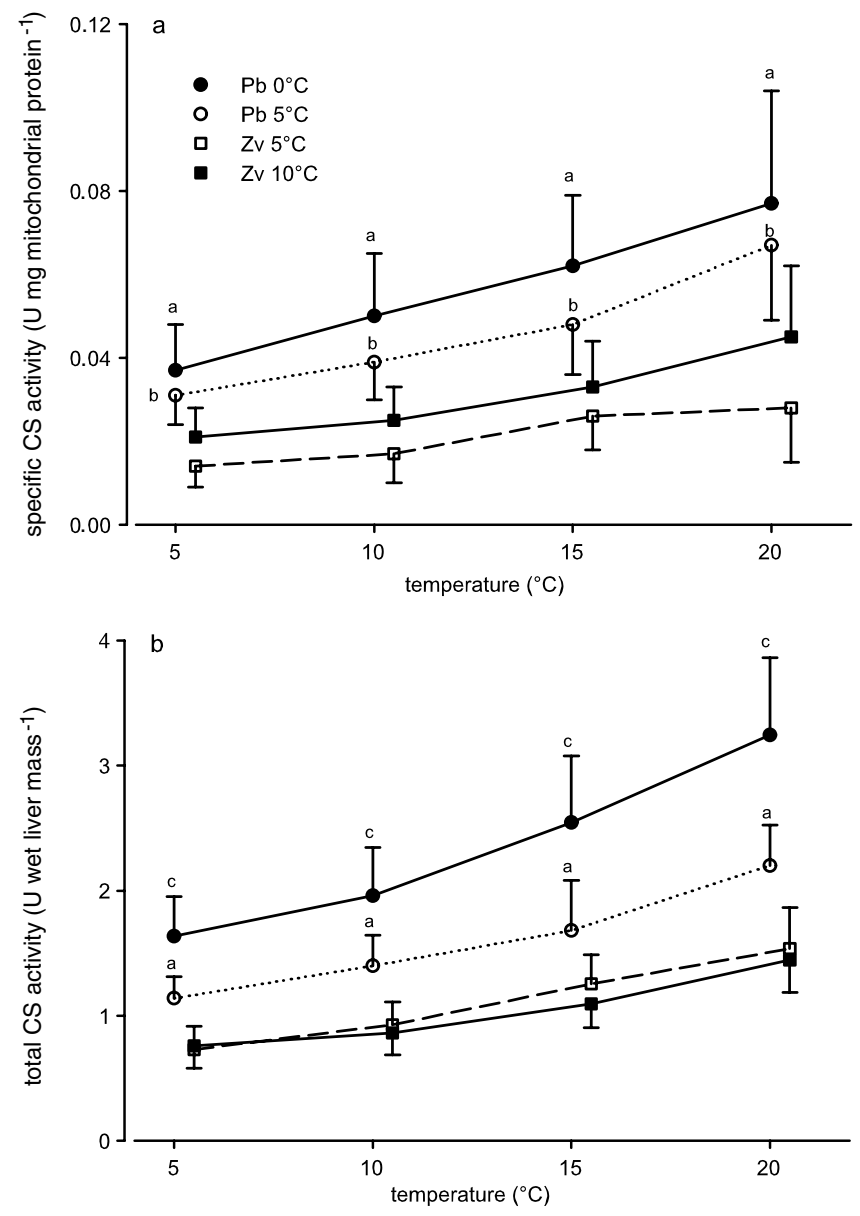

Fig. 5 Temperature dependence of citrate synthase activity (CS), specific (a) and total (b normalized to a $40 \mathrm{~g}$ animal), in liver of Antarctic and North Sea Zoarcidae, in $P$. brachycephalum (Antarctica) under control conditions $\left(0^{\circ} \mathrm{C}\right)$ (filled circles $\left.n=6-8\right)$ and acclimated to $5^{\circ} \mathrm{C}$ (open circles $n=7$ ) and in Z. viviparus (North Sea) acclimated to $5^{\circ} \mathrm{C}$ (open squares $n=4-5$ ) and $10^{\circ} \mathrm{C}$ (control conditions, filled squares $n=5$ ). For better viewing squares were shifted to the right. a indicates data significantly different to data from $Z$. viviparus at $5^{\circ} \mathrm{C}$ and $10^{\circ} \mathrm{C}$, when compared at the same temperature. b indicates data from $P$. brachycephalum at $5^{\circ} \mathrm{C}$ significantly different to data from $Z$. viviparus at $5^{\circ} \mathrm{C}$, when compared at the same temperature. c indicates data from $P$. brachycephalum at $0^{\circ} \mathrm{C}$ significantly different to data from the other acclimation groups, when compared at the same temperature 
higher total CS capacity compared to North Sea eelpout $\left(5^{\circ} \mathrm{C}\right.$ and $\left.10^{\circ} \mathrm{C}\right)$.

For $\mathrm{NADP}^{+}$-dependent IDH activities in the mitochondrial suspension ( $\mathrm{U} \mathrm{mg}$ mitochondrial protein $^{-1}$ ), activities were higher in control $\left(0^{\circ} \mathrm{C}\right)$ Antarctic eelpout than in control $\left(10^{\circ} \mathrm{C}\right)$ and cold acclimated $\left(5^{\circ} \mathrm{C}\right)$ North Sea eelpout at all temperatures (Fig. 6a). Evaluation of IDH activity in the total liver content of a $40 \mathrm{~g}$ animal showed no differences between cold acclimated and control Z. viviparus, but again higher IDH activities in control $\left(0^{\circ} \mathrm{C}\right)$ compared to $5^{\circ} \mathrm{C}$ acclimated Antarctic eelpout (Fig. 6b). Total IDH capacity was significantly higher in the liver of control $0^{\circ} \mathrm{C}$ Antarctic than of $5^{\circ} \mathrm{C}$ and $10^{\circ} \mathrm{C}$ exposed North Sea eelpout, whereas this difference fell at warmer temperatures and IDH capacity in
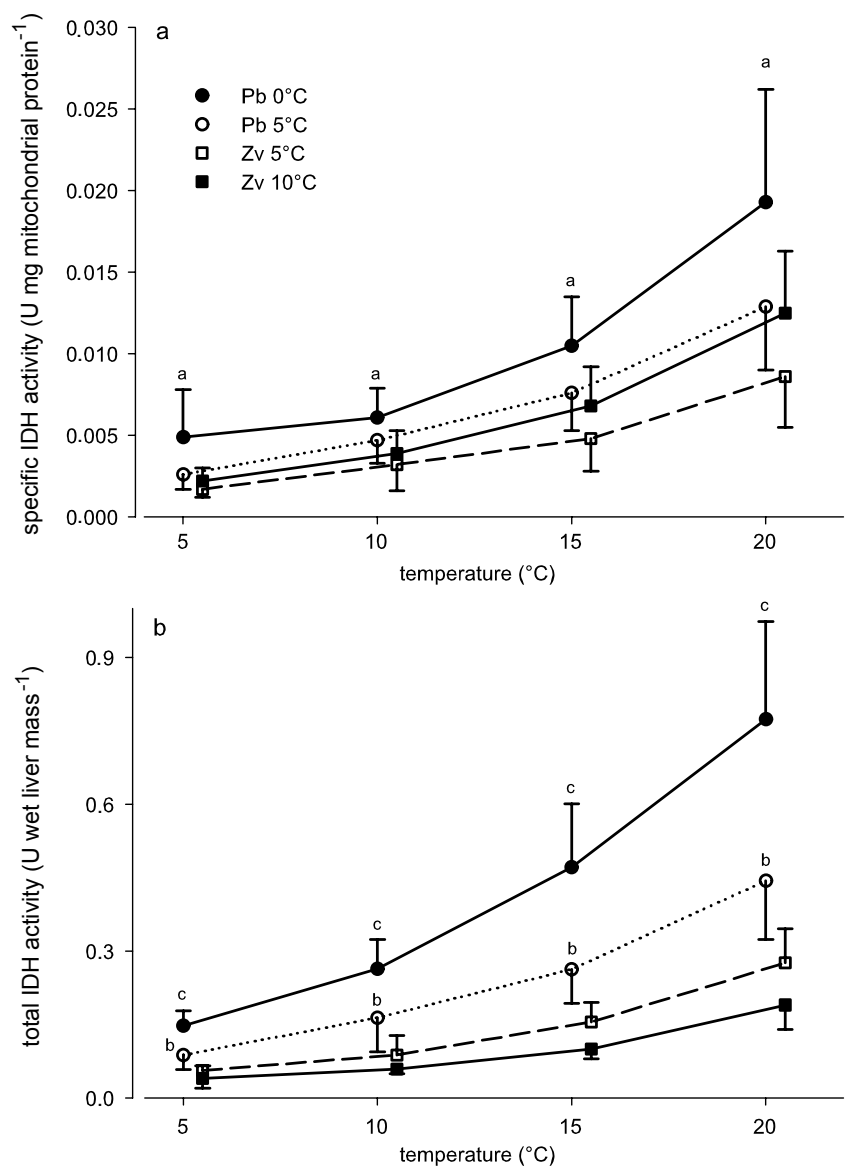

Fig. 6 Temperature dependence of $\mathrm{NADP}^{+}$-dependent isocitratedehydrogenase activity (IDH), specific (a) and total (b, normalized to a $40 \mathrm{~g}$ animal), in liver of Antarctic and North Sea Zoarcidae, in $P$. brachycephalum (Antarctica) under control conditions $\left(0^{\circ} \mathrm{C}\right)$ (filled circles $n=6-8$ ) and acclimated to $5^{\circ} \mathrm{C}$ (open circles $n=5-6$ ) and in $Z$. viviparus (North Sea) acclimated to $5^{\circ} \mathrm{C}$ (open squares $n=3-5$ ) and $10^{\circ} \mathrm{C}$ (control conditions, filled squares $n=4-6$ ). For better viewing squares were shifted to the right. a indicates data from $P$. brachycephalum at $0^{\circ} \mathrm{C}$ significantly different to data from $Z$. viviparus at $5^{\circ} \mathrm{C}$ and $10^{\circ} \mathrm{C}$, when compared at the same temperature. b indicates data from $P$. brachycephalum at $5^{\circ} \mathrm{C}$ significantly different to data from $Z$. viviparus at $10^{\circ} \mathrm{C}$, when compared at the same temperature. c indicates data from $P$. brachycephalum at $0^{\circ} \mathrm{C}$ significantly different to data from the other acclimation groups, when compared at the same temperature liver of $5^{\circ} \mathrm{C}$ acclimated $P$. brachycephalum was significantly higher than in control $\left(10^{\circ} \mathrm{C}\right) \mathrm{Z}$. viviparus only. As for CS activities, no discontinuities were found in Arrhenius plots of IDH activities in the investigated temperature range $\left(5^{\circ} \mathrm{C}-20^{\circ} \mathrm{C}\right.$, data not shown $)$ and $Q_{10}$ values and Arrhenius activation energies $\left(E_{\mathrm{A}}\right)$ did not differ between groups, $Q_{10}=2.9 \pm 0.3$ and $E_{\mathrm{A}}=72.4 \pm 6.3 \mathrm{~kJ} \mathrm{~mol}^{-1}$ for $P$. brachycephalum and with $Q_{10}=3.1 \pm 0.3$ and $E_{\mathrm{A}}=76.5 \pm 5.4 \mathrm{~kJ} \mathrm{~mol}{ }^{-1}$ for Z. viviparus (means \pm standard deviation for control and acclimation groups of each species).

\section{Discussion}

Respiratory properties of liver mitochondria

Liver mitochondria of eelpout, Z. viviparus (North Sea, at $10^{\circ} \mathrm{C}$ and $5^{\circ} \mathrm{C}$ ) and $P$. brachycephalum (Antarctica, at $0^{\circ} \mathrm{C}$ and $5^{\circ} \mathrm{C}$ ) showed a clear negative correlation of respiratory coupling ratios with rising temperature (Fig. 3). The decrease of coupling ratios with temperature was elicited by different thermal sensitivities of oxidative phosphorylation capacity (state III) and proton leakage capacity (state $\mathrm{IV}_{\mathrm{ol}}$ ) showing lower Arrhenius activation energies for state III than for state $\mathrm{IV}_{\mathrm{ol}}$. Progressive uncoupling with rising temperature was also reported by Hardewig et al. (1999) and by Pörtner et al.(1999b) for Antarctic species, whereas studies carried out with temperate zone eurytherms showed coupling ratios to be stable and independent of temperature (Blier et al. 2001, Fischer 2002) or fairly insensitive to temperature (van den Thillart and Modderkolk 1978, Moyes et al. 1988, Blier and Guderley 1993).

These findings, along with the present results of no clear acclimation effect on RCR (higher in $Z$. viviparus after cold acclimation but unchanged in $P$. brachycephalum after warm acclimation) suggest that there is no general pattern of changing mitochondrial coupling ratios with temperature and that patterns are species specific. Despite decreasing coupling ratios with increasing temperature in all groups, only mitochondria of the warm acclimated North Sea and Antarctic eelpout showed the expected concomitant decrease in phosphorylation efficiency ( $\mathrm{ADP} / \mathrm{O}$ ratio) at high temperatures. Pörtner et al. (1999b) found no change in $\mathrm{P} / \mathrm{O}$ ratio with temperature by classical determination (from changes in respiration slopes) but significantly lower $\mathrm{P} / \mathrm{O}$ ratios at high temperatures by biochemical $\mathrm{P} / \mathrm{O}$ ratio determinations. These differences associated with different methods might indicate that the classical determination is not sensitive enough for small changes in $\mathrm{P} /$ O ratios. Hardewig et al. (1999) discussed that unchanged $\mathrm{P} / \mathrm{O}$ ratios, despite progressive uncoupling, might become explainable in classical analyses of $\mathrm{P} / \mathrm{O}$ ratios when maximal phosphorylation rates are determined at low proton motive force and low proton leak, and compared with the subsequent transition to maximum proton leakage at maximum proton motive force. 
Acclimation had no effect on specific maximal phosphorylation capacities (state III in nmol O min ${ }^{-1} \mathrm{mg}$ mitochondrial protein ${ }^{-1}$ ) of liver mitochondria of both eelpout species but rates were lower in Antarctic than in North Sea eelpout. Johnston et al. (1994, 1998) and Guderley (1998) concluded that cold compensation of specific state III respiration does not occur in muscle of various fish from a latitudinal cline (largely Southern hemisphere species). In eurythermal fish from Northern latitudes, however, cold acclimation and adaptation are reflected in increased specific aerobic capacities of mitochondria (Fischer 2002), and it was suggested as an explanation that an increase in the specific phosphorylation capacity typically occurs in cold adapted eurytherms living at variable temperatures but may be negligible in stenothermal animals living at permanently low temperatures (cf. Pörtner et al. 2000). In that respect cold acclimated $Z$. viviparus are more eurythermal than $P$. brachycephalum.

Mitochondrial protein per g liver did not differ significantly between acclimation groups, and was only slightly higher in the cold. Mitochondrial proliferation as shown in muscle (Egginton and Sidell 1989; Johnston et al. 1998) did not thus occur during temperature compensation in liver. As found in previous studies, metabolic cold compensation in liver goes along with an increase in organ size (Kent et al. 1988; Seddon and Prosser 1997; Lannig et al. 2003) and one might expect a decrease in those warm acclimated. This is confirmed by the present paper (Fig. 1). By decreasing mitochondrial protein content with decreasing total liver size, warm acclimated $P$. brachycephalum showed similar patterns of temperature compensation as known for eurythermal fish species, resulting in a similar total hepatic mitochondrial content as found in $Z$. viviparus at the same temperature. This finding would suggest that $P$. brachycephalum has conserved some features of their eurythermal ancestors (see "Effect of warm acclimation on Antarctic eelpout"). Due to different mitochondrial protein contents in total liver, the picture of mitochondrial respiration rates changed after calculation for total liver. Mitochondrial state III respiration in total liver clearly showed cold or warm compensation (Fig. 4a). Our findings are in line with data by van Dijk et al. (1999) who found higher metabolic rates (nmol O min ${ }^{-1}$ $100 \mathrm{~g}$ eelpout $^{-1}$ ) in both cold adapted $P$. brachycephalum $\left(0^{\circ} \mathrm{C}\right)$ and cold acclimated $Z$. viviparus $\left(3^{\circ} \mathrm{C}\right)$ than in warm acclimated $Z$. viviparus $\left(12^{\circ} \mathrm{C}\right)$. However, van Dijk et al. found similar standard metabolic rates in cold acclimated North Sea and cold adapted Antarctic eelpout, therefore, the overcompensation in state III respiration capacities of liver mitochondria of cold acclimated $Z$. viviparus found in the present work does not necessarily imply a concomitant rise in whole animal metabolic rate.

Since mitochondrial proton leakage rates correlate with the standard metabolic rate of an animal (Brookes et al. 1998) and comprise a constant fraction of $20 \%-$ $50 \%$ of standard metabolism in endotherms and most likely ectotherms (Brand 1990; Brand et al. 1994; Brookes et al. 1998), our results indicate that oxygen consumption due to proton leakage through the inner mitochondrial membrane (state $\mathrm{IV}_{\mathrm{ol}}$ ) mirrors elevated metabolic rates in the cold. State $I_{\mathrm{ol}}$ respiration in total liver of polar versus cold acclimated boreal eelpouts revealed no difference and thus, a similar pattern as found for the standard metabolism of eelpouts by van Dijk et al. (1999). Investigation of whole animal respiration rates also revealed similar values in P. brachycephalum acclimated to $0^{\circ} \mathrm{C}$ and $5^{\circ} \mathrm{C}$ (data not shown) despite different state III respiration capacities in the liver.

According to our earlier hypothesis, proton leakage is down-regulated in parallel with standard metabolism in cold adapted stenothemal Antarctic ectotherms (Pörtner et al. 2000), a conclusion supported by proton leakage rates found in bivalves and nototheniods (Pörtner et al. 1999b; Hardewig et al. 1999). However, in the case of the zoarcids, no differences were found in mitochondrial liver state $\mathrm{IV}_{\mathrm{ol}}$ capacity and standard metabolic rate between cold acclimated boreal and polar $\left(0^{\circ} \mathrm{C}\right.$ and $5^{\circ} \mathrm{C}$ acclimation) zoarcids. It is conceivable that the Antarctic zoarcid does not follow the trend found in invertebrates and notothenioids and shows no downregulation of standard metabolism relative to its temperate zone congeners. This is also mirrored in the lack of down-regulation of the mitochondrial proton leak leading again to the conclusion that $P$. brachycephalum has kept some features of their eurythermal ancestor.

\section{Effects of temperature on mitochondrial enzymes}

In ectothermic animals long-term temperature shifts may cause compensatory changes in glycolytic and mitochondrial enzyme levels and capacities (Crockett and Sidell 1990; Torres and Somero 1988; Lannig et al. 2003). These findings are consistent with our present data (Figs. 5, 6). Warm acclimation led only to a slight reduction in specific $\mathrm{CS}$ and IDH activities (U mg mitochondrial protein ${ }^{-1}$ ) in $P$. brachycephalum but in parallel with reduced mitochondrial protein content in liver, total enzyme capacities were significantly decreased by a factor of 1.43 for CS and 1.69 for IDH (measured at $5^{\circ} \mathrm{C}$ ), when compared to $P$. brachycephalum at $0^{\circ} \mathrm{C}$. Cold compensated CS activities after calculation for total liver were also found by Kent et al. (1988) and Lannig et al. (2003), though it is somewhat unexpected that the slightly lower specific enzyme (CS and IDH) activities in liver mitochondria of cold compared to warm acclimated North Sea eelpout remained uncompensated for despite the higher mitochondrial protein content in Z. viviparus acclimated to $5^{\circ} \mathrm{C}$. In contrast to the present findings, Lucassen et al. (2003) found higher CS activity per g liver during cold acclimation $\left(3.5^{\circ} \mathrm{C}\right)$ in North Sea eelpout, however, it might be that cold compensation of CS activities only starts when temperature falls below $5^{\circ} \mathrm{C}$. Lucassen et al. found no differences in hepatosomatic 
indices, whereas, in the present study, cold acclimation led to elevated $I_{\mathrm{H}}$ in $Z$. viviparus. It may well be that longterm cold acclimation (10 months in this study versus 25 days in the study by Lucassen et al. 2003) led to a down-regulation of specific CS capacities associated with an increase in $I_{\mathrm{H}}$.

In general, the highly positive cold compensation of CS but not of IDH activities, shown by higher specific as well as total CS activities in $P$. brachycephalum compared to $Z$. viviparus both acclimated to $5^{\circ} \mathrm{C}$, is likely due to the role of mitochondria not only in energy metabolism but also in anabolic processes, with CS providing excess citrate, for example for enhanced lipid synthesis in the cold (for review cf. Pörtner 2002a, b).

Isocitrate dehydrogenase displayed similar $Q_{10}$ and $E_{\mathrm{A}}$ values as proton leakage rates (state $\mathrm{IV}_{\mathrm{ol}}$ ) and might be involved in setting the mitochondrial proton leakage rate as discussed by Pörtner et al. (2000). High $Q_{10}$ and $E_{\mathrm{A}}$ values indicate that proton leakage might involve an enzyme catalyzed process (Ellory and Hall 1987; Sazanov and Jackson 1994; Pörtner et al. 1999b). However, further investigations of the mechanism of proton leakage are required. The present data indicate that IDH and proton leakage capacities are, if at all, only loosely correlated since the changes in IDH activity did not correlate with the observed changes in $\mathrm{IV}_{\mathrm{ol}}$ state.

\section{Effect of warm acclimation on Antarctic eelpout}

To our knowledge this is the first long-term warm acclimation experiment for a fish species from the stable cold Antarctic ecosystem (Eastman 1993). In former studies Trematomus bernachii and T. newnesi, both species belonging to the Antarctic endemic Notothenioidae, were acclimated to $4^{\circ} \mathrm{C}$ during $2-5$ weeks only and this temperature is the highest to which these fish can be warm acclimated for several weeks (cf. Weinstein and Somero 1998). Some adjustments in metabolism due to temperature changes can occur in notothenioids. Gonzalez-Cabrera et al. (1995) found temperature-induced capacity changes for osmoregulation in Antarctic Notothenioids, $T$. bernachii and $T$. newnesi. Warm acclimation $\left(4^{\circ} \mathrm{C}\right)$ led to decreased serum osmolality, which was a result of the positive compensation of $\mathrm{Na}^{+} /$ $\mathrm{K}^{+}$-ATPase in osmoregulatory tissues. In our study, $P$. brachycephalum was acclimated to $5^{\circ} \mathrm{C}$ for at least 10 months and during this time none of the fishes died. They even showed positive growth (data not shown). Furthermore, the lack of significant differences in condition factors and gonadosomatic indices (Table I) between the different species and acclimation groups, indicate that acclimation to $5^{\circ} \mathrm{C}$ does not stress $P$. brachycephalum. Evidently, P. brachycephalum is still able to undergo temperature compensation despite its life at stable cold temperatures. As in the study of Weinstein and Somero (1998), no temperature-induced changes were found in specific mitochondrial respiration rates but warm acclimation led to decreased aerobic capacities in total liver. Mitochondrial oxidative phosphorylation (state III) and enzyme activities, CS and $\mathrm{NADP}^{+}$-dependend IDH, were lower in total liver of warm versus cold acclimated $P$. brachycephalum due to decreased liver size and mitochondrial protein content in total liver. Since no data are available on liver size and mitochondrial liver protein of $T$. bernachii, it remains unclear whether Notothenioids also show adjustments in aerobic capacities at the whole organ level after warm acclimation.

Zoarcids are most abundant in the North Pacific and North Atlantic as well as in the polar regions of Arctica and Antarctica. They originated in the Eocene about 50 million years ago in the Northern Pacific. Around the Miocene they radiated into the polar waters of Antarctica (Anderson 1994). The confamilial species, the Antarctic eelpout $P$. brachycephalum and the temperate common eelpout $Z$. viviparus show very low levels of standard metabolic rate and a benthic sluggish lifestyle which generally characterizes this family. It might therefore be that in this group, the pressure is less to adjust aerobic metabolism to the permanent cold than in the more active notothenioids. Furthermore, it might be that $P$. brachycephalum has retained some features of a cold adapted but hypometabolic eurytherm, with elevated CS activities but mitochondrial protein contents similar to boreal eelpout acclimated to $5^{\circ} \mathrm{C}$. The finding that $P$. brachycepahalum permanently tolerated and grew at $5^{\circ} \mathrm{C}$ and, evidently, retained the capacity to warm acclimate by reducing liver aerobic capacity may relate to the presence of this species in warmer bottom waters of Antarctica. Zoarcids were not found at the same cold temperatures as the notothenioids (F. Mark, personal communication). Further investigations are required to reveal to what extent aerobic metabolism can be adjusted in other Antarctic ectotherms, or whether down-regulation of aerobic capacities during warm acclimation only exists in Antarctic Zoarcidea.

Acknowledgements The authors would like to thank M. Lucassen for assistance in developing the stabilisation buffer for analysis of $\mathrm{NADP}^{+}$-dependent isocitrate dehydrogenase activity, T. Hirse for support in protein determinations, and E. Brodte for her helpful comments on the manuscript.

\section{References}

Alp RP, Newshole EA, Zammit VA (1976) Activities of citrate synthetase and $\mathrm{NAD}^{+}$-linked and $\mathrm{NADP}^{+}$-linked isocitrate dehydrogenase in muscle from vertebrates and invertebrates. Biochem J 154:689-700

Anderson ME (1994) Systematics and Osteology of the Zoarcidae (Teleostei: Perciformes). Ichthyol Bull 60:120

Blier PU, Guderley H (1993) Mitochondrial activity in rainbow trout red muscle: the effect of temperature on the ADPdependence of ATP synthesis. J Exp Biol 176:145-157

Blier PU, Lemieux H (2001) The impact of the thermal sensitivity of cytochrome c oxidase on the respiration rate of Arctic charr red muscle mitochondria. J Comp Physiol B 171:247-253

Brand MD (1990) The contribution of the leak of protons across the mitochondrial inner membrane to standard metabolic rate. J Theor Biol 145:267-286 
Brand MD, Chien LF, Ainscow EK, Rolfe DFS, Porter RK (1994) The causes and functions of mitochondrial proton leak. Biochem Biophys Acta 1187:132-139

Brookes PS, Buckingham JA, Tenreiro AM, Hulbert AJ, Brand MD (1998) The proton permeability of the inner membrane of liver mitochondria from ectothermic and endothermic vertebrates and from obese rats: correlations with standard metabolic rate and phospholipid fatty acid composition. Comp Biochem Physiol B 119:325-334

Campbell C, Davies P (1978) Temperature acclimation in the teleost, Blennius pholis: changes in enzyme activity and cell structure. Comp Biochem Physiol B 61:165-167

Chance B, Williams GR (1956) The respiratory chain and oxidative phosphorylation. Adv Enzymol 17:65-134

Clarke A (1991) What is cold compensation and how should we measure it? Am Zool 31:81-92

Crockett EL, Sidell BD (1990) Some pathways of energy metabolism are cold adapted in Antarctic fishes. Physiol Zool 63:472488

van Dijk PLM, Tesch C, Hardewig I, Pörtner HO (1999) Physiological disturbances at critically high temperatures: a comparison between stenothermal Antarctic and eurythermal temperate eelpouts (Zoarcidae). J Exp Biol 202:3611-3621

Eastman J (1993) Antarctic fish biology: evolution in a unique environment. Academic, San Diego

Egginton S, Sidell B (1989) Thermal acclimation induces adaptive changes in subcellular structure of fish skeletal muscle. Am J Physiol 256:R1-R10

Ellory JC, Hall AC (1987) Temperature effects on red cell membrane transport processes. In: Bowler K, Fuller BJ (eds.) Temperature and animal cells. Symp Soc Exp Biol 31:53-66

Fischer T (2002) The effects of climate induced temperature changes on cod (Gadus morhua L.): linking ecological and physiological investigations. PhD Thesis, University Bremen

Gonzalez-Cabrera PJ, Dowd F, Pedibhotla VK, Rosario R, Stanley-Samuelson D, Petzel D (1995) Enhanced hypo-osmoregulation induced by warm-acclimation in Antarctic fish mediated by increased gill and kidney $\mathrm{Na}^{+} / \mathrm{K}^{+}$-ATPase activities. J Exp Biol 198:2279-2291

Gornall AG, Bardawill CJ, David MM (1949) Determination of serum proteins by means of biuret reaction. J Biol Chem 117:751-66

Guderley H (1998) Temperature and growth rates as modulators of the metabolic capacities of fish muscle. In: Pörtner HO, Playle R (eds.) Cold ocean physiology. Cambridge University Press, London, pp 58-87

Hardewig I, Peck LS, Pörtner HO (1999) Thermal sensitivity of mitochondrial function in the Antarctic Notothenioid Lepidonotothen nudifrons. J Comp Physiol B 169:597-604

Johnston IA, Guderley H, Franklin CE, Crockford T, Kamunde C (1994) Are mitochondria subject to evolutionary temperature adaptations?. J Exp Biol 195:293-306

Johnston IA, Calvo J, Guderley H, Fernandez D, Palmer L (1998) Latitudinal variation in the abundance and oxidative capacities of muscle mitochondria in perciform fishes. J Exp Biol 201:1-12

Kawall HG, Torres JJ, Sidell BD, Somero GN (2002) Metabolic cold adaptation in Antarctic fishes: evidence from enzymatic activities of brain. Mar Biol 140:279-286

Kent J, Koban M, Prosser C (1988) Cold-acclimation induced protein hypertrophy in channel catfish and green sunfish. J Comp Physiol B 158:185-198

Lannig G, Eckerle LG, Serendero I, Sartoris FJ, Fischer T, Knust R, Johansen T, Pörtner HO (2003) Temperature adaptation in eurythermal cod (Gadus morhua): a comparison of mitochondrial enzyme capacities in boreal and Arctic populations. Mar Biol 142:589-599

Londraville R, Sidell B (1990) Ultrastructure of aerobic muscle in Antarctic fishes may contribute to maintenance of diffusion fluxes. J Exp Biol 150:205-220
Lucassen M, Schmidt A, Eckerle LG, Pörtner HO (2003) Mitochondrial proliferation in the permanent versus temporary cold: enzyme activities and mRNA levels in Antarctic and temperate zoarcid fish. Am J Physiol Regul Integr Comp Physiol 258:1410-1420

Mark FC, Bock C, Pörtner HO (2002) Oxygen-limited thermal tolerance in Antarctic fish investigated by MRI and 31P-MRS. Am J Physiol 283(5):R1254-R1262

Moyes CD, Buck LT, Hochachka PW (1988) Temperature effects on $\mathrm{pH}$ of mitochondria isolated from carp red muscle. Am J Physiol 254(4):R611-R615

Peck LS (1989) Temperature and basal metabolism of two Antarctic marine herbivores. J Exp Mar Biol Ecol 125:1-12

Peck LS (2002) Ecophysiology of Antarctic marine ectotherms: limits to life. Polar Biol 25:31-40

Pelletier D, Guderley H, Dutil JD (1993) Does the aerobic capacity of fish muscle change with growth rates? Fish Physiol Biochem 12:83-93

Pörtner HO (2001) Climate change and temperature dependent biogeography: oxygen limitation of thermal tolerance in animals. Naturwissenschaften 88:137-146

Pörtner HO (2002a) Climate variations and the physiological basis of temperature dependent biogeography: systemic to molecular hierarchy of thermal tolerance in animals. Comp Biochem Physiol A 132:739-761

Pörtner HO (2002b) Physiological basis of temperature dependent biogeography: trade-offs in muscle design and performance in polar ectotherms. J Exp Biol 205:2217-2230

Pörtner HO, Peck LS, Zielinski S, Conway LZ (1999a) Intracellular $\mathrm{pH}$ and energy metabolism in the highly stenothermal Antarctic bivalve Limopsis marionensis as a function of ambient temperature. Polar Biol 22:17-30

Pörtner HO, Hardewig I, Peck LS (1999b) Mitochondrial function and critical temperature in the Antarctic bivalve, Laternula elliptica. Comp Biochem Physiol A 124:179-189

Pörtner HO, van Dijk PLM, Hardewig I, Sommer A (2000) Levels of metabolic cold adaptation: tradeoffs in eurythermal and stenothermal ectotherms. In: Davison W, Williams $\mathrm{CH}$ (eds.) Antarctic ecosystems: models for wider ecological understanding. Caxton Press, Christchurch, pp 109-122

Sazanov LA, Jackson JB (1994) Proton-translocating transhydrogenase and NAD- and NADP-linked isocitrate dehydrogenases operate in a substrate cycle which contributes to fine regulation of the tricarboxylic acid cycle activity in mitochondria. FEBS Lett. 344:109-116

Seddon W, Prosser C (1997) Seasonal variations in the temperature acclimation response of the channel catfish, Ictalurus punctatus. Physiol Zool 70:33-44

Sidell W, Driedzic WR, Stowe DB, Johnston IA (1987) Biomedical correlations of power development and metabolic fuel preferenda in fish hearts. Physiol Zool 60:221-232

Sokolova IM, Pörtner HO (2001) Temperature effects on key metabolic enzymes in Littorina saxatilis and L. obtusata from different latitudes and shore levels. Mar Biol 139:113-126

Somero GN, de Vries AL (1967) Temperature tolerance of some Antarctic fishes. Science 156:257-258

Sommer AM, Pörtner HO (2002) Metabolic cold adaptation in the lugworm Arenicola marina (L.): comparison of White Sea and a North Sea population. Mar Ecol Prog Ser 240:171-182

van den Thillart G, Modderkolk J (1978) The effect of acclimation temperature on the activation energies of state III respiration and on the unsaturation of membrane lipids of goldfish mitochondria. Biochem Biophys Acta 510:38-51

Torres J, Somero G (1988) Metabolism, enzymic activities and cold adaptation in Antarctic mesopelagic fishes. Mar Biol 98:169180

Weinstein RB, Somero GN (1998) Effects of temperature on mitochondrial function in the Antarctic fish Trematomus bernachii. J Comp Physiol 168:190-196 